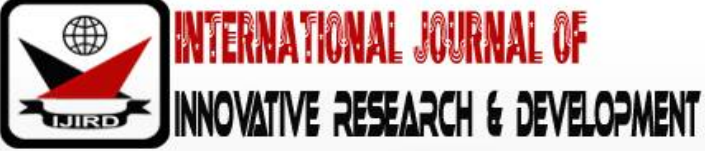

ISSN 2278 - 0211 (Online)

\section{The Role of Non-Farm Income during Variable Rainfall: The Case of Rural Farm Households in Ijere Woreda, Oromia Region, Ethiopia.}

\author{
Biruk Sisay Desulie \\ Lecturer, Department of Rural Development and Agricultural Extension, Ambo University, Ethiopia
}

\begin{abstract}
:
A growing body of empirical evidence shows that rainfall is highly variable throughout Ethiopia. This situation coupled with poor irrigation development, small agricultural land holding, and population pressure forced rural households to diversify their income sources into off-farm and non-farm activities. However, the contribution of these activities to total income of households and their role on reducing vulnerability of farmers to rainfall variability has not been studied. This study, using cross sectional data from Ijere woreda, Oromia regions and employing both descriptive and econometric analysis, attempted to explain the various off-farm \& nonfarm activities, measured their contribution to total household income, and analyzed the role of such incomes on households' vulnerability to rainfall variability. As such, the study found that rural households who participated in off-farm and non-farm activities were able to earn $9.7 \%$ and $7 \%$ of their total income, respectively. Results also indicated that off-farm and nonfarm activities helped participant households to smooth their income over years enabling them to be less exposed to income fluctuation and rainfall variability than nonparticipants. Thus, income diversification is found a significant livelihood strategy to hedge against weather risks - rainfall variability. Yet, Off-farm activities are found to be more of labor intensive and used for day-to-day consumption. In addition, although there is a potential for developing the rural nonfarm economy, the current share of nonfarm income was very limited which was due to the limited/ low profit margins and multiplier effects of the nonfarm activities.
\end{abstract}

Keywords: Nonfarm income, off-farm income, rainfall, Ethiopia

\section{Introduction}

Africa is the poorest continent in the world. It is often characterized as the least developed, technologically backward, food-insecure and the most marginalized continent. Besides, malnutrition, disease, environmental degradation, natural resource depletion, unemployment and weak institutional capacities are among the factors which pose serious development challenges for Africa and Sub-Saharan Africa, in particular (ECA, 2012).

In Sub-Saharan region, agriculture in the major means of livelihood for the rural farmers and the erratic nature of rain is probably the most distinguishing characteristic of Sub-Saharan African agriculture. Masvaya et al. (2008:12)have put it "as smallholder farmers in Sub-Saharan Africa practice rain fed agriculture, they are therefore at high risk of crop failure given the erratic nature of the rains as well as the rainfall variability."Mertz et al. (2008) also stated that farmers in the Sub-Saharan region have always been facing climatic variability at intra- and inter-annual and decadal time scales. In all rural communities, climate is one of the factors influencing households coping and adaptation strategies to environmental changes (Adger, 1999). Hence, coping and adaptation strategies have traditionally included crop diversification, mobility, livelihood diversification, and migration Mertz et al. (2008).

Ethiopia, like other Sub-Saharan African countries, shares most of those challenges and characteristics. The country's economy is mainly dependent on agriculture which accounts for 42percent of the GDP (MoFED, 2011). The agriculture, given its huge share in GDP, is mainly characterized by extreme dependence on rainfall which is proved to be highly variable throughout the country (Cheunget al., 2008). Rainfall is often erratic and unreliable. And rainfall variability and associated droughts have historically been major causes of food shortages and famines in rural areas (Seleshi and Zanke, 2004).Million (2010) also indicated the fact that drought is the number one risk not only for rural Ethiopians, but also for the country as a whole.

By recognizing the nature of agriculture sector, the Ethiopian government has devised plans targeted to agricultural development. Currently, the main focuses of agriculture and rural development plan are extensive use of labor, proper utilization of agricultural land, strengthening agricultural marketing, irrigation development and income diversification (MoFED, 2010).

Amongst, income diversification has shown a growing importance for the contemporary rural households. According to Ellis (1999), empirical evidence from a variety of different locations suggests that rural households do indeed engage in multiple activities and rely on diversified income portfolios. For instance, in Sub-Saharan Africa, a range of 30-50 percent reliance on non-farm income sources is common; but it may attain 80-90 percent in southern Africa. In 
south Asia, on average, roughly 60 percent of rural household income is from non-farm sources. In Ethiopia, approximately 25percent of all households in rural Ethiopia own one or more nonfarm enterprises. However, about 2percent of households exclusively rely on nonfarm activities (Rijkers et al., 2002).In this study, following Leones's (1998) definition, nonfarm income is any source of income not generated through agricultural activities. And off-farm income is any agricultural income that is earned away from the family's farm.

Various reasons for rural livelihood diversification have been documented in development literatures. According to Ellis (2000), the reasons for households to adopt multiple livelihood strategies are risk (in relation to climate), coping strategies(involuntary response to unanticipated failure), seasonality (returns to labor time), labor markets (in relation to education, skills, location and gender), credit markets (availability of funds), and asset strategies (future income generating capabilities). By category, Barrett et al. (2001) indicated two motives: push factors and pull factors. Push factors includes land constraints, population pressure, landholdings fragmentation, reaction to crisis, etc. And pull factors comprises realization of strategic complementarities between activities, such as crop-livestock integration, specialization according to comparative advantage accorded by skills or endowments.

Nevertheless, even though considerable studies have been done on off-farm and nonfarm income diversification activities in Ethiopia (e.g. Mintewab et al., 2010; Woinishet, 2010; Adugna et al., 2012; Lemi, 2006; Block and Webb, 2001), they did not show the significance of off-farm and nonfarm income during weather shocks such as rainfall variability. Thus, this study intended to investigate the contribution of nonfarm activities to rural household income and assess their role in reducing vulnerability to variable rainfall, taking the c smallholders in Ejere woreda, West Shewa zone, Oromia region. As such, the specific objectives of the study are: (1) to identify the various nonfarm income diversification activities in the study areas; (2) to measure the contribution/ share of off-farm and nonfarm incomes to total household income, and (3) to analyze whether households with nonfarm income sources are less vulnerable tovariable rainfall.

\section{Research Methods}

\subsection{Description of the Study Area}

West Shewa zone is one of the zones in the Oromia regional state located at the central part of thestate. West Shewa is bordered on the south by the Southwest Shewa Zone and the Southern Nations, Nationalities and Peoples Region, on the southwest by Jimma, on the west by East Welega, on the northwest by Horo Gudru Welega, on the north by the Amhara Region, on the northeast by North Shewa, and on the east by Oromia Special Zone Surrounding Finfinne(West Shewa Zone, Agriculture Office, 2017).

Based on the 2007 Census conducted by the Central Statistical Agency of Ethiopia (CSA), this Zone has a total population of 2,058,676, of whom 1,028,501 are men and 1,030,175 women. With an area of 14,788.78 square kilometers, West Shewa zone has a population density of 139.21. A total of 428,689 households were counted in this Zone, which results in an average of 4.80 persons to a household, and 415,013 housing units.

Altitude of West shoa zone ranges from 1000 to 3500 meters above sea level, where the largest area lies between 2000 and 2500 meters above sea level. Topography of the zone; which is mainly leveled field with main drainage basins like Abay, Ghibe and Awash; makes it an ideal place for agriculture (West Shewa Zone, Agriculture office, 2017).

Agriculture provides the largest share to the livelihood of the population in West Shewa. Agriculture is dependent on rainfall as there is lack of adequate knowledge, skill and infrastructure in irrigated agriculture. Crop-livestock mixed farming system is the common practice. The zone is an ideal place for market oriented crop and livestock commodity development as it is endowed with resources necessary for production and have good access to urbanmarkets e.g. Addis Ababa, Holeta and Ambo town.

According to World Bank (2004) memorandum, the average rural household has 1.4 hectare of land (compared to the national average of 1.01 hectare of land and an average of 1.14 for the Oromia Region)and the equivalent of 0.7 heads of livestock. And 31.8percent of the population of the zone is in non-farm related jobs, compared to the national average of 25percent and a Regional average of 24 percent.

Ijere woreda is one of the 18 woredas found in West Shewa zone, Oromia regional state.It is surrounded by Wolmera woreda in the East, Dendi and Jeldu woreda in the South, Sebeta Hawasi and Ilu woreda in the West, and Ada Berga and Meta robi woreda in North.The total population of the woreda is 99,062 (49,829 male and 49,233 female) of which a total of 86,581 (43984 male and 42597 female) live in rural area(West Shewa Zone, Agriculture Office, 2015). the woreda has a total of 15,733 rural households with 15,329 housing units (CSA, 2007)

The woreda covers a total of 56,918 ha land of which 40,985 ha is used for agriculture, 4,456 ha is covered with forest, 4,446 ha is grazing land, while 7,031 ha is available for other purposes. With regards to climate, 45percent of the woreda lies in Tropical (Dega) zone, while 55percent lies in Temperate (Woina Dega) zone. The altitude of the woreda ranges from 2060 - 3085m above sea leve. And on average, the woreda recieves an annual rainfall of $1200 \mathrm{~mm}$, while average tempreture is $22^{\circ} \mathrm{C}\left(28^{\circ} \mathrm{C}\right.$ maximum and $9{ }^{\circ} \mathrm{C}$ minimum). In addition, The major agricultural products in the woreda are Wheat, Barley, Bean, Oil seed, Maize, Haricot Beans, Sorghum and Linseed (West Shewa Zone, Agriculture Office, 2017). 


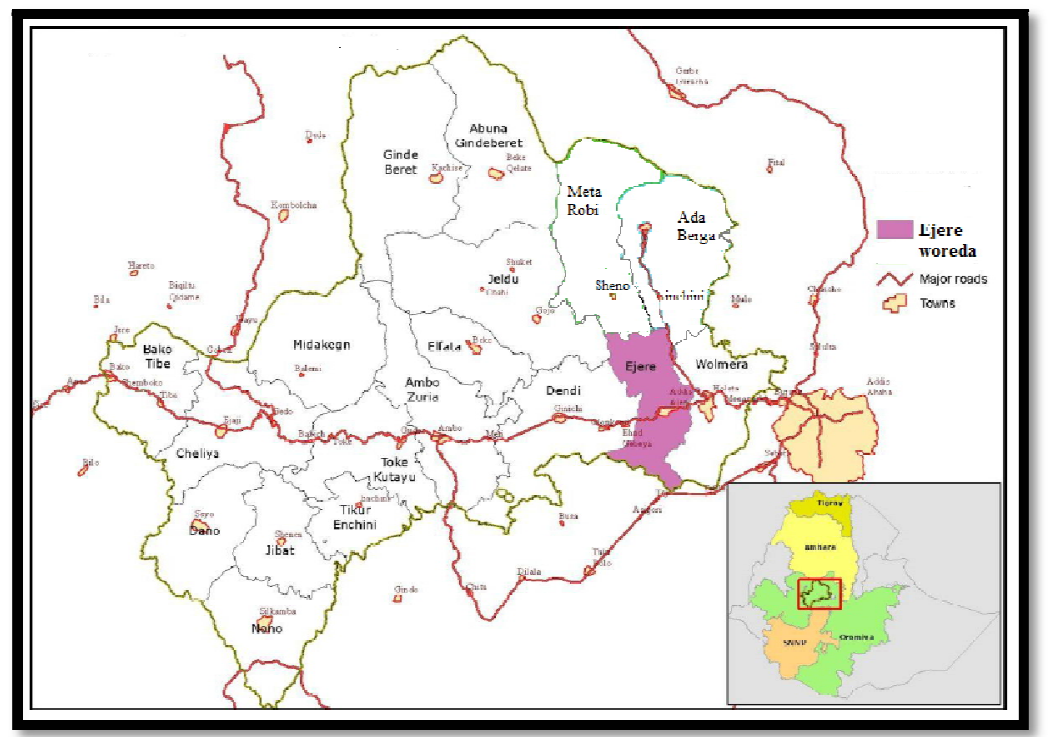

Figure 1: Geographical Location of Ejere Woreda (The Study Area)

Source: Adopted from West Shewa Zone, Agriculture Office (2017)

\subsection{Source and Type of Data}

To study the different nonfarm activities income and their role on households' vulnerability to rainfall variability, this study used both primary and secondary data sources. The primary data were collected through household questionnaire addressed to the sample rural farm households in the study area. The collected data through household questionnaire included major variables of interest such as socio-economic characteristics of sample households, nonfarm income/ activities, consumption expenditures, livestock sales/ ownership, and agricultural production and/ or sales, among others.

In addition, the study used secondary data sources (e.g. monthly and annual rainfall) for the rainfall analysis. Rainfall data were collected from the Metrological agency in the woreda.

\subsection{Sampling Procedure and Sample size}

The cost of studying an entire population is usually prohibitive to both researchers and those being studied in terms of privacy, time, and money. Consequently, a subset or sample of a given population must be selected. An important goal of sampling is to provide a practical and economic mechanism to enable extrapolation from a sample to a population (Patrick, 2008).

For this study, Ijere woreda was purposively selected. The woreda have good access to urban markets like Addis Ababa, Ijere (Addis Alem) town, Holeta town, and Oromia Special zone, where wage work (one of nonfarm income) is common. Woineshet (2010) has indicated proximity to urban centers is one the determinants of off-farm and non-farm participation.

As such, in Ejere woreda, there are 15,733 rural households in 27 different kebeles (CSA, 2007). To draw sample households, this used two stages simple random sampling technique. In the first stage, 6 kebeles were randomly selected out of a total 27 kebeles found in the woreda.

In the second stage, to determine a sample household size, the study based on the Kothari's sample size determination. According to Kothari (2004), when the population size (N) if finite, the formula to determine the sample size $(\mathrm{n})$ is given by:

$\mathrm{n}=\frac{\mathrm{Z}^{2} \cdot \mathrm{p} \cdot \mathrm{q} \cdot \mathrm{N}}{\mathrm{e}^{2}(\mathrm{~N}-1)+\mathrm{Z}^{2} \cdot \mathrm{p} \cdot \mathrm{q}}$

Where; $\mathrm{n}=$ sample size

$\mathrm{N}=$ population (in this case, total households are 15,733 )

$\mathrm{Z}=$ the value of the standard variate at a given confidence level (in this case, $\mathrm{Z}=1.96$ using 95percent confidence level)

$\mathrm{p}=$ sample proportion, and $\mathrm{q}=1-\mathrm{p},(\mathrm{p}=0.5$ to have maximum sample size with the desired precision)

$\mathrm{e}=$ the acceptable error (in this case 5percent since confidence level is 95percent)

Thus, the sample size (n) for this study is calculated as follows;

$\mathrm{n}=\frac{1.96^{2} * 0.5 * 0.5 * 15,733}{0.05^{2}(15,733-1)+1.96^{2} * 0.5 * 0.5}$

$\underline{\underline{\mathrm{n}=375.03}}$ 
As such, 375sample households from the selected kebeles were drawn using a simple random sampling procedure for the household questionnaire survey. The random selection of farm households were based on the list of household heads found in each kebeles and proportional to the population.

2.4. Data Analysis

This study applied both descriptive and econometric analysis relevant to the data characteristics and the research objectives. The data were processed and analyzed using Stata statistical software.

\subsubsection{Descriptive Analysis}

Descriptive analyses were made to explain the various nonfarm activities and measure their amount and contributions to households' total income. Descriptive statistics such as mean, standard deviations, and percentage were used, while statistical tools such as T-test and Chi-square test were used for comparing mean values of variable of interest and/ or for checking associations/ correlations.

\subsubsection{Econometric Analysis}

In order to examine the role of nonfarm income on households' total income during variable rainfall, or in another word, to access the impact of participation into nonfarm income sources on households' vulnerability to variable rainfall, the study specified the commonly used method the so called an Ordinary Least Square (OLS) multiple regression model. Following Gujarati (2004), the study will base its analysis on the model:

$y_{i}=\beta_{1}+\beta_{2} x_{2 i}+\beta_{3} x_{3 i}+\cdots+\beta_{k} x_{k i}+u_{i}$

Where, $\mathrm{y}_{\mathrm{i}}$ is the dependent variable forith observation?

$\mathrm{X}_{2 \mathrm{i}}, \mathrm{X}_{3 \mathrm{i}}, \ldots \mathrm{X}_{\mathrm{ki}}$ are the explanatory variables for $\mathrm{i}^{\text {th }}$ observation

$\beta_{2}, \beta_{3}, \ldots \beta_{\mathrm{k}}$ are coefficients of explanatory variables

$\beta_{1}$ is the constant term

$u_{i}$ is the error term for $i^{\text {th }}$ observation

As such, a separate regression for nonfarm participants and non-participants were specified. In another word, the dependent variable (total income) was specified by splitting households into participants and non-participants controlling key independent variables. The independent variables were chosen on criteria such as, number of significant variable, model fit, interest of this study, and priori studies. The model is fitted by checking for the problem of multicollinearity using correlation matrix, and $\mathrm{R}^{2}$ value of the model.

\section{Results and Discussion}

\subsection{Off-Farm and Nonfarm Activities in the Study Area}

In the study area, the major off-farm activities identified were hiring out labor, labor exchange, hiring out oxen, renting out land, and participating in food for work activities. The income driven from these off-farm activities is shown in figure below.

It is found that more than half percent (51percent) of households' off-farm income comes from food for work activities (Fig 2) Food for work is participating in government-arranged activities, like road cleaning, soil management practices, planting trees, etc., in an exchange for cash and/ or relief. It isone of the Employment Generation Scheme (EGS) of the government which is mainly issued during weather shocks or disasters as a safety net program(Million, 2010). Hence, the highest income collected from food for work would imply that participation in food for work activities is common and the households in the study area may exposed to such risks as weather shocks.

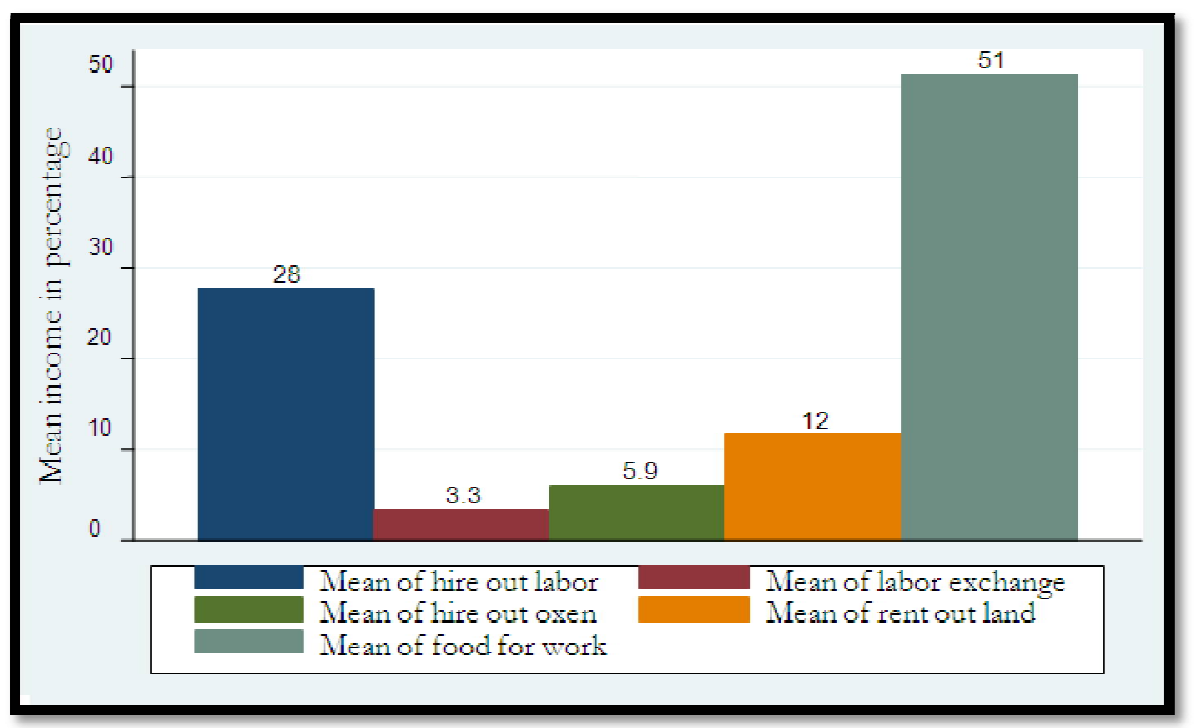

Figure 2: Percentage of Income from Different off-Farm Activities Source: Own Household Survey, 2018 
The second highest off-farm income is from hiring out labor (28percent). Hiring out labor refers to households' participation in wage earning activities outside their farm in agricultural activities. Since labor endowment is an important asset for rural households, it would be obvious to expect more income from hiring out labor. This is followed by renting out land, contracting out ones' own land for money to somebody else, which constitutes 12percent of the total off-farm income. In addition, although households generate relatively smaller income, they hire out their oxen for temporary period in return for cash, which is 6percent of the off-farm income. The least off-farm income comes from labor exchange which is around 3percent. Labor exchange is working on somebody's farm in reciprocal relation. That means a household work on agricultural activities for someone in return for the same activities from the other. This is usually performed during crop harvesting seasons.

Likewise, the study also found that the main nonfarm income sources include sale of firewood, sale of handicraft, sale of beverage, petty trade, grain mill, migrant income, remittance, assistances, gifts, food aid, and other businesses.

Accordingly, the first five highest nonfarm incomes come from petty trade (31percent), other businesses (18percent), sale of firewood (12percent), sale of handicrafts (9percent), and remittance (9percent) (Fig. 3). It is important that the income from petty trade took the largest share of the nonfarm income. Previous study in the region also indicated that given population pressure and diminishing arable land size, petty trade has become an important source of nonfarm income. In a poorly developed rural enterprise, an increasing petty trade may develop into medium scale enterprise to contribute more to the rural economy, provided that the necessary attention is given for the sector.

Other businesses such as livestock/ crop trading, knitting, producing and selling traditional clothes have become the second important nonfarm income. A firewood sale, which is environmentally damaging, is the third largest nonfarm income source. This can be because selling firewood is an easy option with no startup cost that rural households can choose than involving in beverages and handicraft sales, among others. Remittance income from relatives living abroad is also among the important contributor to households' nonfarm income. These days, rural women migration to Middle East countries can be the reason for remittance income of farmers. Other incomes sources such as assistance received from domestic relatives, migrant income, gifts, food aid, etc. have relatively low share of total nonfarm income.

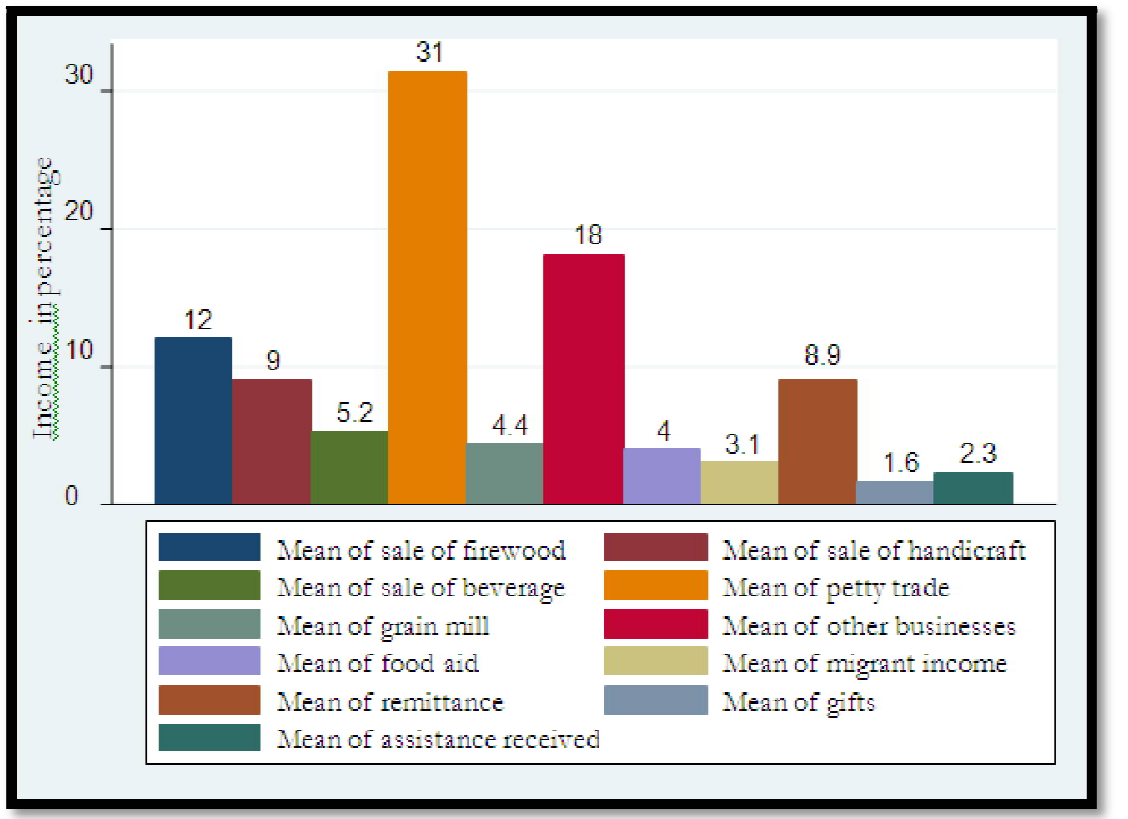

Figure 3: Percentage of Income from Different Nonfarm Activities

Source: Own Household Survey, 2018

\subsection{The Contribution of Off-Farm and Nonfarm Income to Total Household Income}

First, we will discuss the share of off-farm income from the total household income in comparison with the nonparticipants' income sources. Off-farm income is the amount of earning from off-farm activities. Woineshet (2010) has used wage work and self-employment income as off-farm income. Mintewab et al. (2010) also considered daily laborer and food for work as off-farm activities. In this study, off-farm income is the sum of incomes from hiring out labor, labor exchange, hiring out oxen, food for work and renting out land.

As such, it is found that both participants and non-participants derived their major income from own production i.e. Total Value of Consumption from own production (TVC) (Fig. 4). This result is consistent with the characteristics of farmers in the study areas, who engaged more in farming activities. Non-participants get the next biggest total income share from crop sales (37percent) while this is just about 11 percent for participant households. And non-participants get the lowest total income share from livestock sales (0.44percent) while this is around 3.5percent for participant household. 


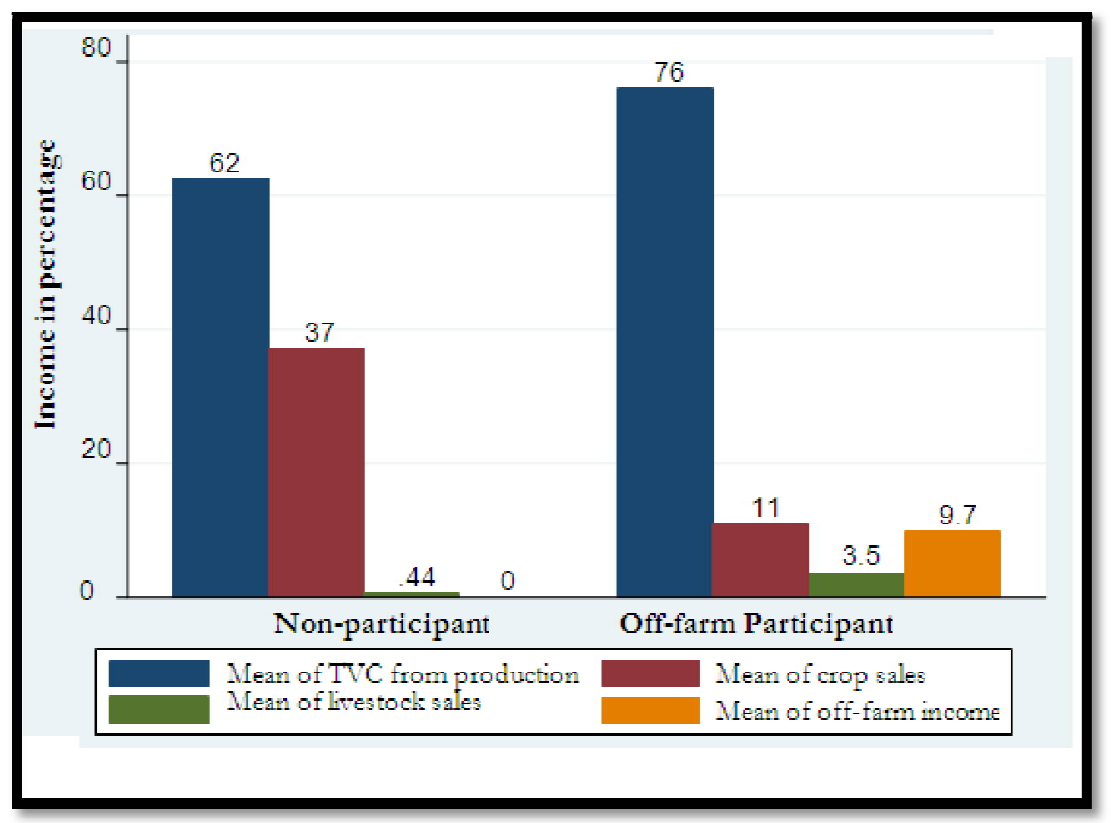

Figure 4: The Share of Various Incomes of off-Farm

Participant and Non-Participant

Source: Own Household Survey, 2018

However, participants have an additional income source - off-farm income - having a share of 9.7percent of the total income. Previous studies, for instance, Lemi (2006) has indicated that the share of off-farm income was 13percent of total income of farmers in Ethiopia. Gebrehiwot et al.,(2012) put it as 8 percent of total income of farmers in Northern Ethiopia while Adugna et al., (2012) put it as 13 percent of total income of farmers in Southern Ethiopia. Despite the few differences on the share across regions, off-farm income is useful for participant households. Since most of such additional income source is used to complement the agricultural incomes during slack seasons or in response to weather shocks, they could have a role in smoothing household consumptions.

Nevertheless, the nature of off-farm activities has to be considered to appropriately decode their relevant implication for the rural economy. For one thing, the majority of these activities are labor intensive and for the other, about half of the off-farm incomes come from food for work whose return is often in small kind or cash. Hence, farmers use these incomes for their day-to-day consumption, leaving no/ little future probability of asset accumulation. Thus, transforming off-farm participants from those less productive/ return activities to those activities that have a likelihood of generating an incremental income would be one possible initiative, as far as off-farm activities are concerned.

On the other hand, coming to the nonfarm income, the contribution of nonfarm income to total household income of the participant was made in comparison with the nonparticipant. Nonfarm income, in this study, is the sum of income from sale of firewood, sale of handicraft, sale of beverage, petty trade, grain mill, migrant income, remittance, assistances, gifts, food aid, and other businesses.

As such, with nearly similar result compared to off-farm participants, both nonfarm participant and nonparticipant households get majority of their income from own production (Total Value of Consumption from own production (TVC) (Fig 5). Since, agriculture is the main occupation in the study areas it could be normal to expect majority of the income from consumption of own production. The next biggest income came from crop sales that take 37\% for nonparticipant households, while it is about $14 \%$ for participant households. In other words, the amount of sale crops sales by the nonparticipants is nearly three times higher than the participants. This may indicates that farmers, relying on only agricultural income, have to depend on their crops whenever cash is required. And such risks as crop failure or weather shocks could more likely disturb their consumption pattern than others.

Besides, it is found that nonfarm income contribute only $6.9 \%$ to the total income. This is too small compared to other regions/ countries. For instance, in Sub-Saharan Africa, in general, the share ranges from 30 - 50 percent of total income in Africa. In south Asia, on average, roughly 60 percent of rural household income is from non-farm sources (Ellis, 1999). Thus, it may depict how far rural Ethiopia lags behind in expanding rural non-farm economy. 


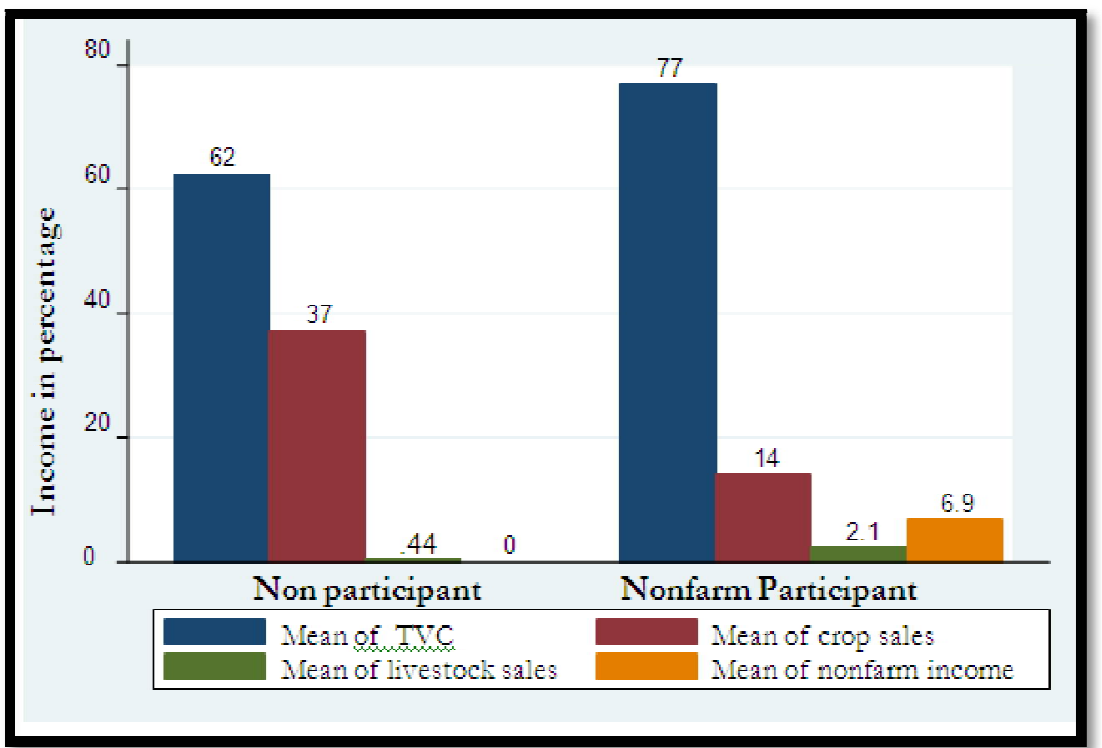

Figure 5: The Share of Various Incomes of Nonfarm Participant and Nonparticipant Source: Own Household Survey, 2018

In general, even though the off-farm and nonfarm incomes are small in amount, it is interesting to know whether this income diversification strategy is really significant in smoothing consumption/reduce vulnerability to shocks for smallholder.

\subsection{Income Diversification and Rainfall Variability}

Climate variability has a significant impact on the livelihoods of the rural poor in developing countries. While literature on climate change considered income diversification as one of agricultural adaptations to climate shocks (e.g. Bruke and Lobell, 2010: Below et al., 2010), those of rural livelihood studies put climate as one the determinant of income diversification among rural farmers (e.g. Elis, 1999). And while the formers admit the complex process of agricultural adaptation as it is evolutionary and occurs in the context of climatic, economic, technological, social, and political forces that are difficult to isolate (Below et al., 2010), the later ones generally view those factors as 'pull' and 'push' factors (Barrett et al., 2001), considering climate related variables as one of push factors. Either ways, it is clear that income diversification and climate variability are obviously associated in the discourse of rural farm households.

In here, as per earlier discussions, it seemed that diversification into most off-farm and nonfarm activities is mainly driven by some push factors. Considering the climate variability as some those factors, an attempt was made to see effect of variability on the income of rural households and the role of income diversification (off-farm and nonfarm) in mitigating weather shocks. This is particularly of interest where farmers, in highland area, are mainly dependent on agricultural income and the off-farm and nonfarm incomes are small.

To this end, a OLS regression was specified, considering seasonal rainfall amounts along with socio-economic variables as explanatory variables and the result is displayed on Table 1. As such, it is found that,even though the variability of rainfall put the rural households under vulnerable context, the income diversification into nonfarm and offfarm activities has helped rural households in smoothing consumption over years. Results indicated that, over years, the seasonal rainfall variations have positive net effect on the total income of nonfarm and off-farm participant, unlike the nonparticipants. Here, the positive increase of the participants' income is mainly attributed to the dry (bega) season. This is could be due to the fact that dry (bega) season is an off-season where farmers search for income sources other than the agricultural activities, despite the driving forces behind. 


\begin{tabular}{|c|c|c|c|}
\hline $\begin{array}{c}\text { Dependent Variable: } \\
\text { Log of Total Income }\end{array}$ & $\begin{array}{c}\text { Off-Farm } \\
\text { Participants }\end{array}$ & $\begin{array}{c}\text { Non-Farm } \\
\text { Participants }\end{array}$ & Nonparticipants \\
\hline Independent variables & Coefficients & Coefficients & Coefficients \\
\hline Main rainy season (Kiremt) & $-0.0082^{* *}$ & $-0.0040^{* *}$ & $-0.0015^{*}$ \\
& $(0.003)$ & $(0.0019)$ & $(0.0006)$ \\
\hline Light rainy season (Belg) & $-0.0221^{* *}$ & $-0.0308^{* * *}$ & $-0.0412^{* * *}$ \\
& $(0.008)$ & $(0.0060)$ & $(0.0058)$ \\
\hline Dry season (Bega) & $0.0634^{* *}$ & $0.086^{* * *}$ & $0.0239^{* * *}$ \\
& $(0.007)$ & $(0.0043)$ & $(0.0041)$ \\
\hline Male headed households & 0.022 & -0.043 & 0.037 \\
& $(0.018)$ & $(0.031)$ & $(0.034)$ \\
\hline Education (years of schooling) & $0.047 * *$ & $0.081^{* *}$ & 0.008 \\
& $(0.021)$ & $(0.022)$ & $(0.032)$ \\
\hline Farming experience (years) & -0.004 & 0.011 & -0.007 \\
& $(0.005)$ & $(0.009)$ & $(0.008)$ \\
\hline Kebele works (1=yes, 0=no) & -0.049 & -0.052 & -0.023 \\
& $(0.084)$ & $(0.073)$ & $(0.083)$ \\
\hline Family size (number) & -0.022 & 0.010 & 0.027 \\
& $(0.026)$ & $(0.019)$ & $(0.035)$ \\
\hline Male labor (number) & 0.093 & 0.066 & $0.094^{* *}$ \\
& $(0.079)$ & $(0.058)$ & $(0.040)$ \\
\hline Female labor (number) & 0.014 & -0.018 & 0.001 \\
& $(0.064)$ & $(0.060)$ & $(0.091)$ \\
\hline Farm size (plots) & 0.0005 & 0.0001 & 0.0006 \\
& $(0.0003)$ & $(0.0001)$ & $(0.0008)$ \\
\hline Constant & $25.929^{* *}$ & $19.49513^{* * *}$ & $14.3600^{* * *}$ \\
& $(4.230)$ & $(2.7210)$ & $(2.3482)$ \\
\hline Pro>F & 0.0000 & 0.000 & 0.0000 \\
\hline Number of Obs. & 76 & 151 & 142 \\
\hline 2 & 0.8972 & 0.9173 & 0.9388 \\
\hline
\end{tabular}

Table 1: OLS Regression Result: Factors Affecting Total Household Income by Participation $* \mathrm{P} \varangle 0.10$, ** $\mathrm{P} \measuredangle 0.05$, *** $\mathrm{P} \measuredangle 0.01$

Numbers in Bracket () Indicate Standard Errors

Source: Own Household Survey, 2018

Contrary to dry season, the light rainy (belg) and main rainy (kiremt) seasons reduced the total income of the participants and nonparticipants. In rural Ethiopia, the light rainy season is the time where farmers get back to their farm works. For instance, this season is planting time for Maize, Beans, Root crops (Yam, Cassava, Taro and Irish potato) and Enset (false banana) (Bush, 2002). Thus, households usually spend their time on their own farm and incur costs for seeds. As a result, the season's effect in reducing the income of the households could be normal to expect. Likewise, the main rainy (Kiremt) season also reduced households' income, but only in very small percentages. This could be because, during the main rainy season, rural farmers usually harvest and sell fresh crops and vegetables which they planted during the prior season - light rainy season. This is consistent with the result of previous studies. For instance, according to Bush (2002), this season brings some sort of income to the rural farmers from selling fresh maize, beans, sweet potato, etc. Hence, the reduction in income of the farmers during this season is very small, holding other things remain constant.

So, the effect of the seasonal rainfall variations on the total income of rural farmers has become apparent. Over years; while participants compensated their reduced income during the light and main rainy season by the increase in income during the dry season, the nonparticipant lose by greater amount than they get during dry seasons. Even the dry season increase of the nonparticipant total income is not explained by nonfarm and off-farm activities, unless for farm income such as crop selling. As such, nonfarm activities, even better than off-farm activities, are found important in smoothing farmers' income and reducing their vulnerability to variable rainfall.

Among other socio-economic characteristics included in the regression; education (years of schooling), unlike for nonparticipants, significantly increased the income of participant households. This could imply that as rural households attain an additional year of schooling, they tend to see job opportunities in the non-agricultural sector. Since, most activities in non-agricultural sector requires some education levels, the income generated thereof could normally be influenced by the educational level.

In addition, male labor force is found to have significant and positively impact on the income of nonparticipants. Remaining insignificant for the participants, an increase in male labor force increased the nonparticipants' income by $9.4 \%$. This indicate that farm households primarily allocate male labor forces to agricultural activities than nonfarm and off-farm activities, which in turn imply a higher income return of male labor from agricultural activities. 


\section{Conclusion and Implications}

This study has revealed the importance of income diversification into off-farm and nonfarm activities. Income diversification is found a significant livelihood strategy to hedge against weather risks - rainfall variability. It has helped rural farmers to have smooth consumption or stable income across time and to be less vulnerable to variable rainfall. In contrary, the prevalence of annual and seasonal rainfall variations has negatively affected the income of farmers who depend on only agricultural income.

As far as off-farm activities are concerned, considering the nature of the activities is important to pass their relevant implication for the rural economy. Off-farm activities are found to be more of labor intensive and used for day-today consumption, leaving no/ little future probability of asset accumulation. Thus, transforming off-farm participants from those less productive/ return activities to those activities that have a likelihood of generating an incremental income would be one possible initiative. However, the gain from these activities could not be denied as it fill farmers' consumption gap periodically.

In addition, there is also a likelihood of developing the rural nonfarm sector. There are numerous nonfarm activities in the study areas, where agriculture is still the dominant activity. However, despite the potential for growing nonfarm economy, the share of nonfarm income was very limited compared with Sub Saharan countries, for instance. This was generally due to limited/ low profit margins and multiplier effects of the nonfarm activities. This is evidenced by the finding that the main nonfarm activities such as petty trade, sale of handicraft, and other businesses (livestock/ crop trading, knitting, producing and selling traditional clothesetc.). Hence, investing in rural nonfarm economy through supportive policy instruments like rural financial services would be of importance.

\section{References}

i. Adger W. (1999). Social vulnerability to climate change and extremes in coastal Vietnam. World Development,27, 249-269.

ii. Adugna E. and Wagayehu B. (2012). Determinants of livelihood strategies in Wolaita, southern Ethiopia, Agricultural Research and Reviews,1(5), 153 -161.

iii. Barrett C.B, T. Reardon and P. Webb. (2001). Nonfarm Income Diversification and Household Livelihood Strategies in Rural Africa: Concepts, Dynamics, and Policy Implications, mimeo.

iv. Block S. and Webb P. (2001). The dynamics of livelihood diversification in post-famine Ethiopia, Food Policy,26, 333-350.

v. Bush, J. (2002). Baseline Report on Household Food Economy Assessment: Damot Sore woreda, Wolaita Zone SNNPR, Action for Development (AFD).

vi. Cheung W., Gabriel B. Senay and Ashbindu Singh. (2008). Trends and spatial distribution of annual and seasonal rainfall in Ethiopia, International Journal of Climatology, DOI: 10.1002/ joc.1623.

vii. CSA (Central Statistics Agency). (2007). Summary and statistical report of the 2007 population and housing census, Federal Democratic Republic of Ethiopia (FDRE) population census commission. Addis Ababa, Ethiopia.

viii. ECA (Economic Commission for Africa). (2012). Assessing Regional Integration in Africa V: UNECA, Addis Ababa, Ethiopia.

ix. Ellis, F. (1999). Rural Livelihood Diversity in Developing Countries: Evidence and Policy Implications: Overseas Development Institute (ODI).

x. Ellis, F.(2000). The Determinants of Rural Livelihood Diversification in Developing Countries, Journal of Agricultural Economics, 51(2), 289-302.

xi. Gebrehiwot Weldegebrial Gebru and Fekadu Beyene. (2012). Rural household livelihood strategies in droughtprone areas: A case of Gulomekeda District, eastern zone of Tigray National Regional State, Ethiopia.Journal of Development and Agricultural Economics, 4(6), 158-168.

xii. Gujarati D.N. (2004). Basic Econometrics. $4^{\text {th }}$ ed. The McGraw-Hill Companies.

xiii. Lemi Adugna. (2006). The Dynamics of Income Diversification in Ethiopia: Evidence from Panel data. Economics Faculty Publication Series. Paper 10.

xiv. Masvaya E. N., W. Mupangwa and S. J. Twomlow. (2008). Rainfall variability impacts on farmers' crop management strategies: International Crops Research Institute for the Semi-Arid Tropics (ICRISAT) - Bulawayo, Zimbabwe.

xv. Mertz O., Mbow C., Reenberg A. Diouf A. (2008). Farmers' Perceptions of Climate Change and Agricultural Adaptation Strategies in Rural Sahel, Environmental Management, 43, 804-816.

xvi. Million Tadesse. (2010). Risk coping startegies, public works and fertilizer use in southern highlands of Ethiopia. In Million Tadesse. 2010. Essays on Contracts, Risk Coping and Technology Adoption in Ethiopia. Norwegian University of Life Sciences, School of Economics and Business, Ås, Norway.

xvii. Mintewab Bezabih, Zenebe Gebreegziabher, Liyousew GrebreMedhin, and Gunner Köhlin.(2010). Participation in Off-Farm Employment, Risk Preferences, and Weather Variability: The Case of Ethiopia, Discussion Paper Series, EfD DP 10-21.

xviii. MoFED (Ministry of Finance and Economic Development). (2010). Growth and Transformation Plan (GTP) 2010/ 11-2014/ 15. Addis Ababa, Ethiopia.

xix. MoFED (Ministry of Finance and Economic Development). (2011). Annual Report on Macroeconomic Development. Addis Ababa. Ethiopia.

xx. Rijkers Bob, Mans Soderbom and Francis Teal. (2008). Rural Non-farm Enterprises in Ethiopia: Challenges and Prospects. Breifing Note. 
xxi. Seleshi Y, Zanke U. (2004). Recent changes in rainfall and rainy days in Ethiopia. International Journal of Climatology,24, 973-983, DOI: 10.1002/ joc.1052.

xxii. Woinishet Asnake. (2010). Participation into off-farm activities in rural Ethiopia: who earns more? A Research Paper, The Hague, The Netherlands.

xxiii. World Bank. (2008). World Development Report 2008: Agriculture for Development, The International Bank for Reconstruction and Development. Oxford University Press, New York. 